\title{
The impact of economic sanctions on Russian economy and the RUB/USD exchange rate
}

\section{Ladislav Tyll}

Department of Strategy, University of Economics, Prague

Crech Republic

ladislav.tyll@vse.cr.

\section{Karel Pernica}

Department of Strategy, University of Economics, Prague

Crech Republic

karel.pernica@vse.cz.

\author{
Markéta Arltová \\ Department of Statistics and Probability, University of Economics, \\ Prague \\ Crech Republic \\ arltova@vse.cr.
}

Abstract. Current economic situation in Russia could be considered at least as dismal. Russian population, being largely under the influence of their political elite and mass media, blames Western countries that have been imposing economic sanctions on Russia. In this paper, we are trying to provide an objective overview of the impact of Western sanctions on some incremental economic indicators within the period from 02/01/2013 till 07/11/2016 and challenge the common opinion of many Russians. Looking at Russian economy which is highly dependent on oil exports it may sound obvious that besides Western sanctions and consequent Russian countermeasures, it would be rather the oil prices which have a fundamental effect on the living standards of many Russians. Considering also the Russian dependency on the imports of food and other products we may conclude that the exchange rate between ruble and USD has the most significant impact on the price level in the country and thus on the overall economic environment. We also tried to provide a statistically proven evidence that despite the general proclamations of the Russian Central Bank, the exchange rate of ruble is tightly bound to oil prices since the introduction of sanctions and thus there is no unmanaged floating rate anymore between ruble and USD. 
Keywords: exchange rate ruble/USD, oil prices, Russia, sanctions, countermeasures.

JEL Classification: E32, E44, E58, F31, F51

\section{INTRODUCTION}

When reading different articles including newspaper articles, tweets, blog posts or students' papers regarding the ongoing tension between Western countries and Russia and regarding the current economic situation in the Russian Federation we could observe that many of them start with the same simple quote: "Due to of Western sanctions..."

The goal of this paper is to provide better understanding what was the actual impact of imposed sanctions on Russia, its economy and the living standards of Russian population. We believe that from the perspective of Russian citizens it is the exchange rate of ruble which affects their lives a lot since the country relies on imports for up to 40 per cent of its food supplies (Hille, 2014) and the situation is very much similar in case of other consumer products. We also believe that the impact of sanctions is often deliberately misinterpreted and that there are rather other factors like oil prices and the dependency on oil exports which make Russian economy struggling.

To test our assumptions, we have observed the impact of oil prices on the ruble exchange rate from 02/01/2013 till 07/11/2016 and we tried to understand what was the actual effect from the imposed Western sanctions on Russia.

\section{SANCTIONS AS A COERCIVE MEASURE IN INTERNATIONAL ENVIRONMENT}

Sanctions represent one of the coercive diplomatic measures in international relations. It is one of the most powerful tools used in foreign affairs policy (except from the military intervention) and many governments or international groupings are exploiting it only in case of emergency, when all other measures failed to prevent other from undesired behaviour.

The main goal and purpose of such punitive measures is to achieve international peace and security. An alternative view on the goals of punctuative restrictions is provided by Giumelli (2011: 32-35):

a) signalling - a sign of concern over the current behaviour,

b) restrictions - an attempt to dissuade the government or state from the expected future misconduct,

c) coercion - attempt to change the current behaviour of the government or the state.

Different authors (Hufbauer et al., 2007; Caruso, 2003; Kaempfer \& Lowenberg, 2007) distinguish between three basic types of sanctions. Firstly, there are diplomatic sanctions (reluctance to proceed with mutual international relations), secondly financial ones (suspension of development aid, limited access to the World Bank loans, investment restrictions and freezing of assets) and thirdly trade restrictions (restrictions on imports and exports, trade embargos).

Governments very often tend to combine all three above mentioned types of sanctions in a form of so called "smart sanctions", which are targeting exclusively on a certain industry or individuals directly responsible for misbehaviour igniting adoption of restrictive measures which prevents from seriously affecting innocent civilians (Larn, 1990). Exactly this type of sanctions was employed by European Union in case of Russia in 2014. 
Russian Federation is facing the Western sanction in connection with its actions in the Crimea and in eastern Ukraine. This unprecedented violation of international law could not be left without response, and so the European Union, together with its partners (US, Canada, Australia, Japan, Norway, Switzerland) (Dreyer \& Popescu, 2014) forced the adoption of a series of restrictive measures which were supposed to make Russia to stop interfering into the internal politics of a sovereign state.

There were many measures taken against Russia in this respect. In case of diplomatic coercion, the G8 summit was cancelled in Sochi (2014) and the G7 summit (without Russian attendance) was organized in Brussels instead. EU countries also supported the suspension of negotiations over Russia's joining the OECD and the International Energy Agency. The EU-Russia summit was cancelled and EU member states decided not to hold regular bilateral summits. Bilateral talks with Russia on visa matters as well as on the New Agreement between the EU and Russia were suspended as well. Because these measures turned to be not very effective EU was forced to employ even stricter instruments specifically in connection with the escalation of the situation in eastern Ukraine. (European Union, 2016).

The European Union called its non-military coercion measures in this case as "Restrictive measures" and their imposition was decided under the Common Foreign and Security Policy exclusively by European Council, whose members consist of the Heads of States or Governments of all 28 member countries (Council of the European Union, 2014). The initial imposition of restrictive measures on the Russian Federation was decided by the European Council on March 17th 2014 in response to Russia's annexation of Crimea.

Restrictive measures imposed by EU on Russia included following:

a) Arms embargo - export and import ban on trade in arms and other military materials, incl. export ban for dual-use goods for military use or military end users in Russia, ban on technical aid. This is applicable also on formerly signed contracts (e.g. Mistral case) (Tran, 2015).

b) Asset freeze and travel restrictions - 152 individuals and 37 entities are subject to an asset freeze and a travel to EU territory ban over their responsibility for actions which undermine or threaten the territorial integrity, sovereignty and independence of Ukraine. This restriction is applicable until March 2017.

European Union imposed on 29 to 31 July 2014 on Russia a package of "economic sanctions" targeted at specific sectors of the Russian economy. Despite fairly widespread myth about the devastating impact of the European economic sanctions on the Russian economy, their list is relatively short, and mainly concerns the denial of access of eleven largest Russian state-owned companies, banks and their affiliates on the European financial markets and a ban on the export of sensitive technologies for exploration and production of oil, gas and mineral resources. Namely there are the following economic sanctions:

c) EU nationals and companies may no longer buy or sell new bonds, equity or similar financial instruments with a maturity exceeding 30 days, issued by five major state-owned Russian banks; three major Russian energy companies; three major Russian defence companies; subsidiaries outside the EU of the entities above, and those acting on their behalf or at their direction.

d) EU nationals and companies may also not provide loans with a maturity exceeding 30 days to the entities described above.

e) Ban on exports of certain energy-related equipment and technology to Russia are subject to prior authorisation by competent authorities of Member States. Export licenses will be denied if products are destined for oil exploration and production in waters deeper than 150 meters or in the offshore area north of the Arctic Circle, and projects that have the potential to produce oil from resources located in shale formations by way of hydraulic fracturing. (European Union, 2014) 
In connection with the refusal of the illegal annexation of Crimea and Sevastopol, the EU also adopted following special restrictive measures:

a) import ban on goods from Crimea and Sevastopol, as well as restrictions on trade and investment related to certain economic sectors and infrastructure projects;

b) ban on supply of tourism services in Crimea incl. mooring (excl. emergencies);

c) export ban on goods and technologies to Crimea and Sevastopol designated for transportation, telecommunications and energy, prospecting, exploration and extraction of oil, gas and mineral resources;

d) there is also a ban on technical and financial aid, brokerage, construction and engineering services related to the above-mentioned sectors.

\section{RUSSIAN COUNTERMEASURES}

By now (January 2017) the Russian Federation has not officially admitted its military presence in Ukraine. Not to lose its face and credit in the eyes of Russian public, president Putin and its ruling party imposed a set of countermeasures against the EU and its partners. Their impact was immediately and strongly reflected in everyday life of Russian citizens. The follow up negative effects on living standards of many Russians were consequently deliberately misinterpreted by majority of local media as the result of European sanctions.

Russia cut down governmental spending on purchases of certain machinery and some light industry products and especially imposed a ban on imports of selected agricultural products from countries which imposed or joined sanctions against Russia. From August 7, 2014 up to now there has been a ban on imports of beef, pork and poultry meat and meat products, than ban on imports of fish, crustaceans, molluscs, milk and milk products, fruits and vegetables, malt extract and food products to the Russian Federation (Moscow, 2014).

Russia is largely dependent on food imports, and these restrictions thus caused not only a temporary shortage of food, but also a steep increase in their prices, which in tandem with falling oil prices and the weakening of the ruble adversely affected the already high inflation rate (Mirzayev, 2015).

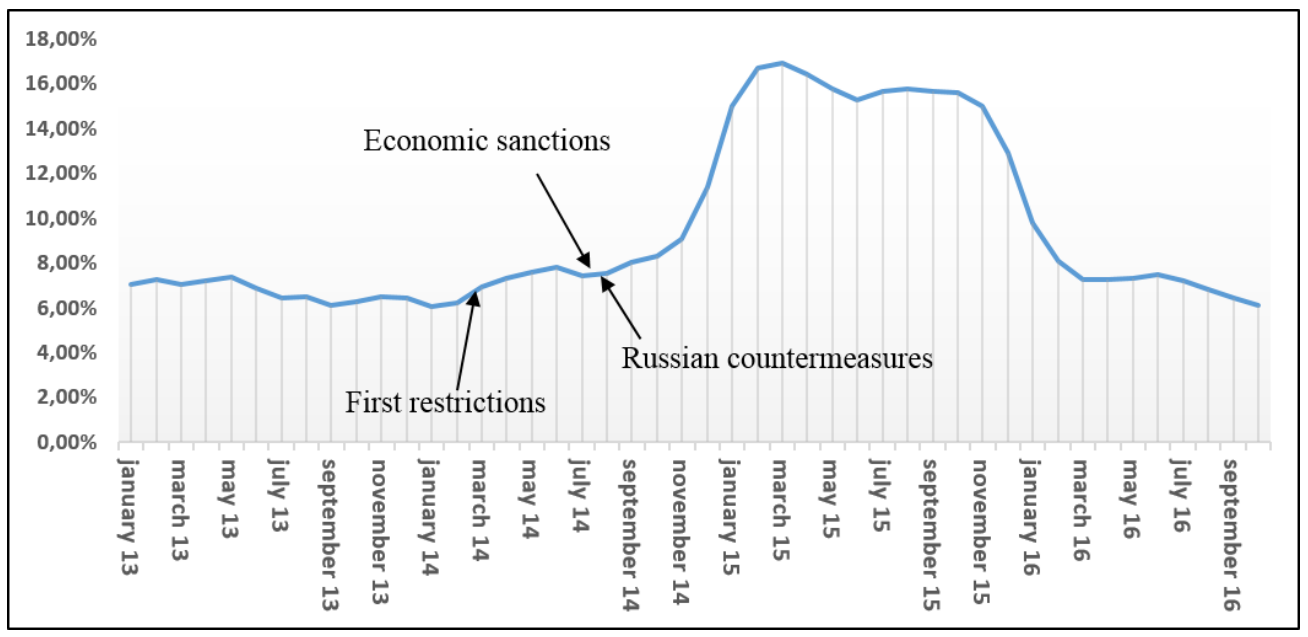

Figure 1. The Year to Year Inflation Rate in Russian Federation

Source: StatBureau (2016) 


\section{OIL AND RUSSIA}

Indeed, a major impact on Russia's economy had declining oil prices during 2014 which dropped from a price of around $\$ 115$ per barrel to the price of $\$ 60$ per barrel at the end of the year. After a slight recovery at the beginning of 2015 , oil prices were falling within the rest of the year. They reached its bottom on January 20,2016, when a barrel of oil was traded at a price of $\$ 27.1$. Currently, the oil is being traded in a range between $\$ 40-50$ per barrel, which is still desperately short for needs of the Russian economy (Investing.com, 2016a).

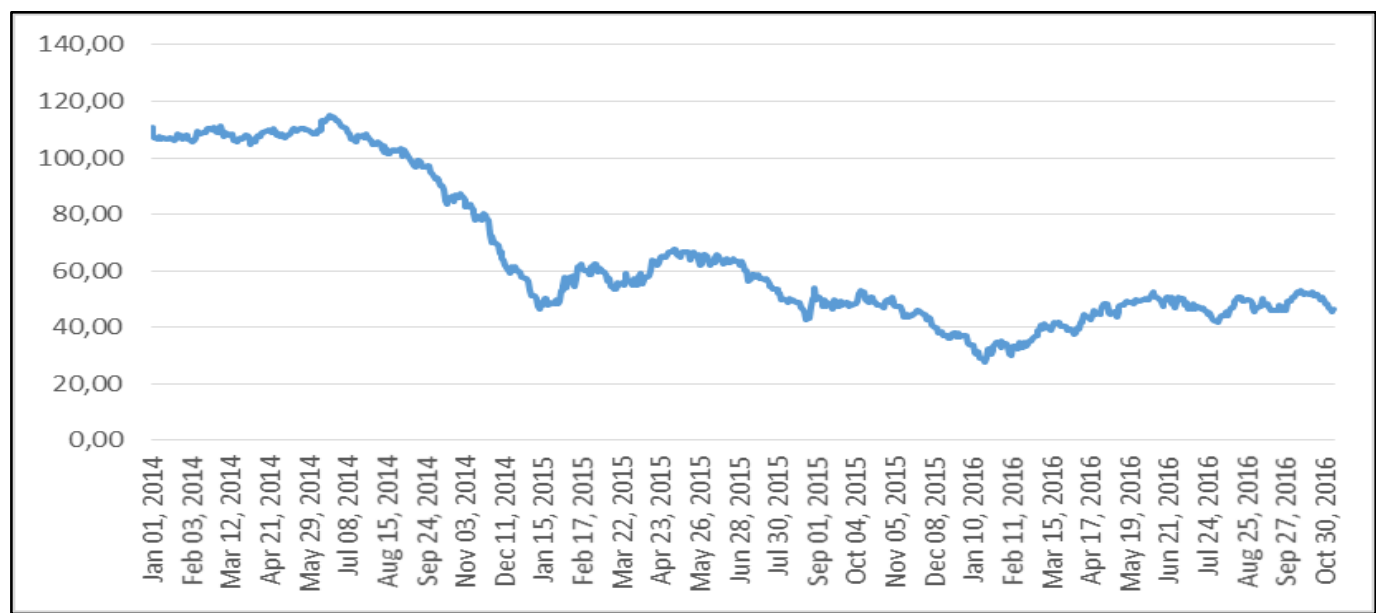

Figure 2. Evolution of the Brent oil price (USD/bbl)

Source: Investing.com (2016a).

The price of oil began to drop due to the excess of supply in the oil market, which is mainly related to the development of shale oil production in the USA. Thanks to the enormous increase in mining capacity the US became fully independent from imported oil within few months and traditional oil exporters had to shed their surplus on the world market, which pushed prices down. Finally, we need to include political influences, especially inconsistencies in OPEC (disputes between Iran and Saudi Arabia), whose members, despite falling oil prices increased their production in order to cover their defaults in oil dependent budgets, which resulted paradoxically in further oil price decline. There are also unconfirmed theories that oil prices are artificially maintained low by Arab countries that have the lowest costs of extraction, and thus they are trying to liquidate the new American competitors who are below their break even at current low oil prices. (Tarver, 2015)

\section{ECONOMIC DEPENDENCE ON THE OIL PRICE}

Mining and quarrying represents one of the most important sectors of the components of the Russian economy (Bolotov, 2013). Therefore, the development of world oil prices has a significant impact on Russian economy. Revenues from oil exports accounts for approximately one half of all Russia's federal revenues and they represent more than two thirds of overall exports. At the times of rising oil prices Russian economy had become fully dependent on incomes from this vital commodity and then it has not been able to compensate its lower prices even by increased gas exports since oil accounts for more than $80 \%$ of total revenues in Russia's export mix of energy raw materials. (Dreyer \& Popescu, 2014)

When the oil price fell by nearly 50\% down from 6/2014 until 1/2015 Russia got into serious economic difficulties of a fiscal nature. This huge shortfall in governmental revenues Russia managed to 
offset at least partially from the reserve fund which had been regularly filled by revenues from oil exports during the times of high oil sales prices. During the years 2015 and 2016 Russia has drawn off almost two thirds of disposable funds to cover the state budget deficit and according to the most optimistic estimates of the Russian minister of finance its total volume will be reduced to $\$ 7,9 \mathrm{bn}$ in the next three years. That would represent the decline by almost 90\%. (Worldwide Financial Services Monitor, 2016). If the oil price would not increase in the meantime, Russia can get into serious economic problems.

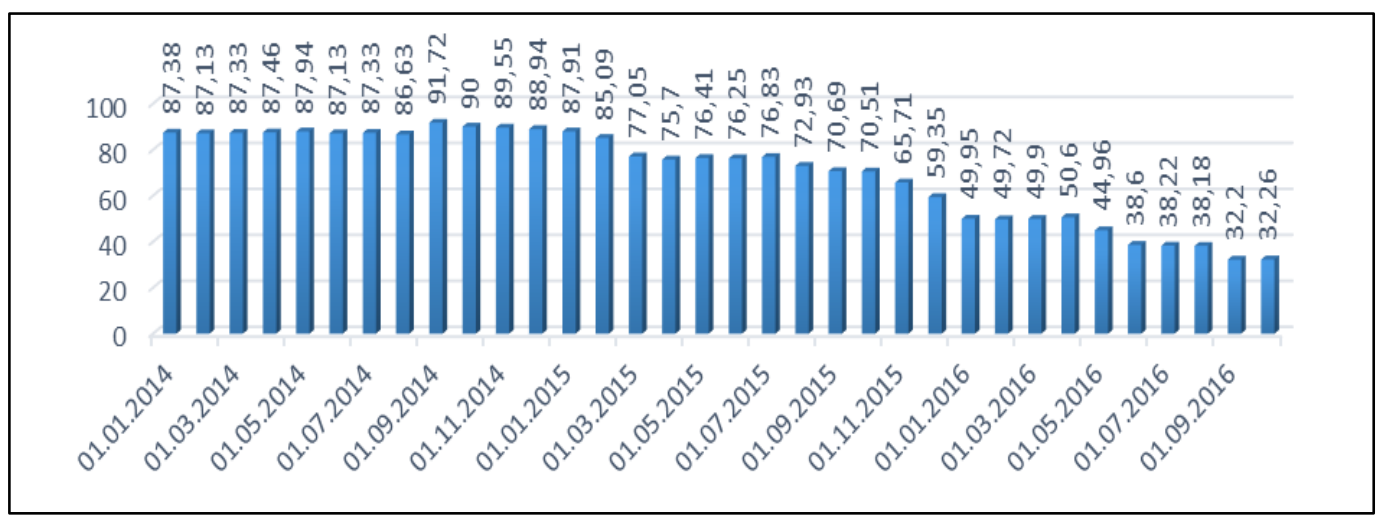

Figure 3. Dynamics of the state reserve fund (billion USD)

Source: Ministry of Finance of the Russian Federation (2016).

Besides the Russian economy, it is also Russian ruble which is extremely sensitive to oil price fluctuations. It has considerably devaluated in response to oil price decline. Introduced sanctions from Western countries as well as Russian countersanctions could be other driver to even deeper devaluation of ruble. All these measures understood by investors as a negative signal were followed by a significant outflow of private capital from Russia. During 2014 there was led out capital in total amount of \$151.5bn from the Russian Federation, which is $\$ 90 \mathrm{bn}$ more than during the same period in 2013. That exceeded the record from the crisis year 2008, which amounted to $\$ 133.6 \mathrm{bn}$. (Reuters, 2015).

In addition to the outflow of capital there was nearly a complete freeze of new inflows of foreign direct investments. Before the crisis almost $75 \%$ of FDIs had been coming from EU countries. In connection with sanctions and due to a reduced outlook at Russian economy the FDIs declined by $30 \%$ in 2014. In 2015 the decline was even deeper when it reached 92\%. (Central Bank of Russian Federation, 2016) The lack of capital in Russia resulted in a significant increase in interest rates. The combination of lack of FDIs and high interest rates led to the suspension or complete cancellation of a large number of investment projects (Dreyer \& Popescu, 2014). If we would add to these problems also the ban on imports of key modern mining infrastructure, we may expect that Russia would likely face reduced competitiveness and other related problems. 


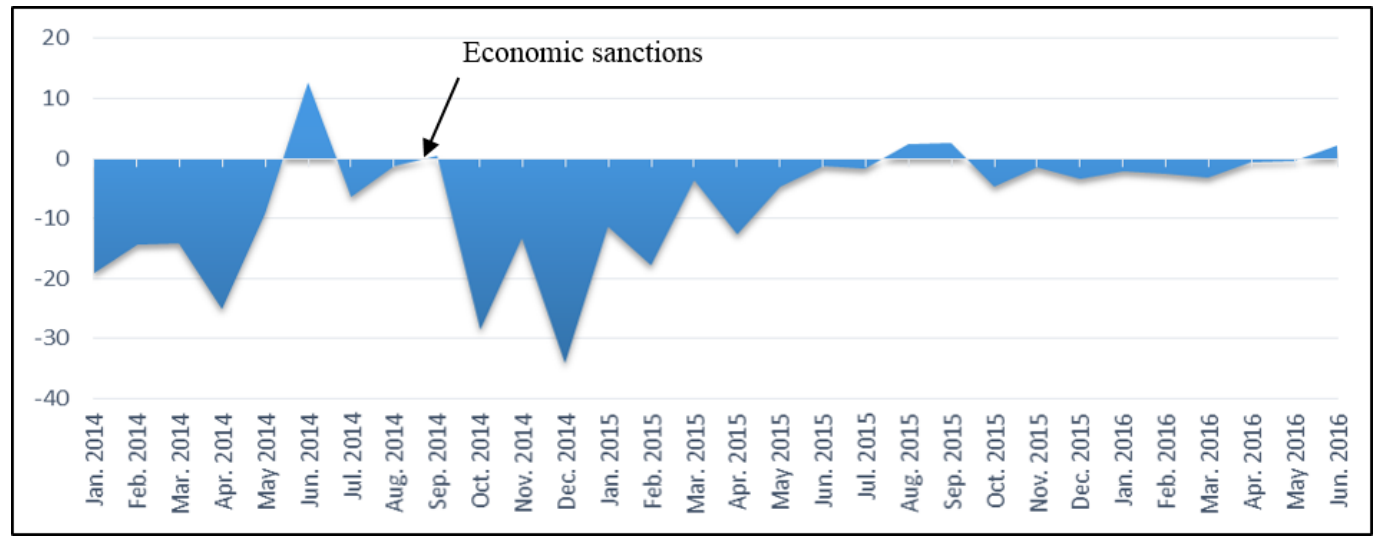

Figure 4. Net flows of capital (billions of USD)

Source: Central Bank of the Russian Federation (2016).

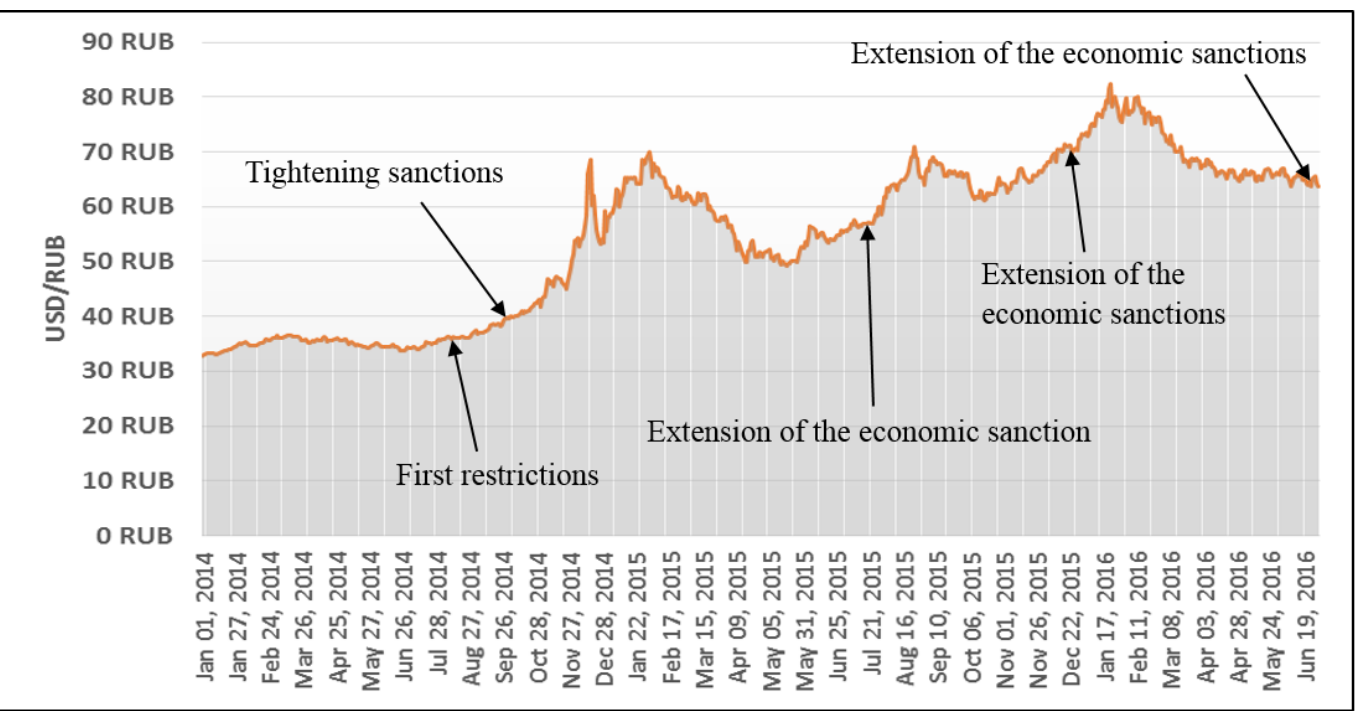

Figure 5. Forex USD/RUB

Source: Investing.com (2016b).

\section{SANCTIONS AND RUBLE IN RELATION TO OIL PRICES}

Looking at Figure 5 it might seem at first glance that imposing economic sanctions had a striking effect on the ruble exchange rate. In the period immediately after the announcement of the imposition or extension of economic sanctions the Russian currency always weakened due to above mentioned factors. In such a case we could consider imposing sanctions on Russia by the EU as an evident success.

The situation is yet much more complicated. If we intersperse the exchange rate data with the oil prices daily data (Figure 6), we would find out that straight after imposing or extending sanctions on Russia there used to be a steep decrease in oil prices. If we even compare the shape of both curves we would find a significant correlation between the oil price and the exchange rate of the ruble. 


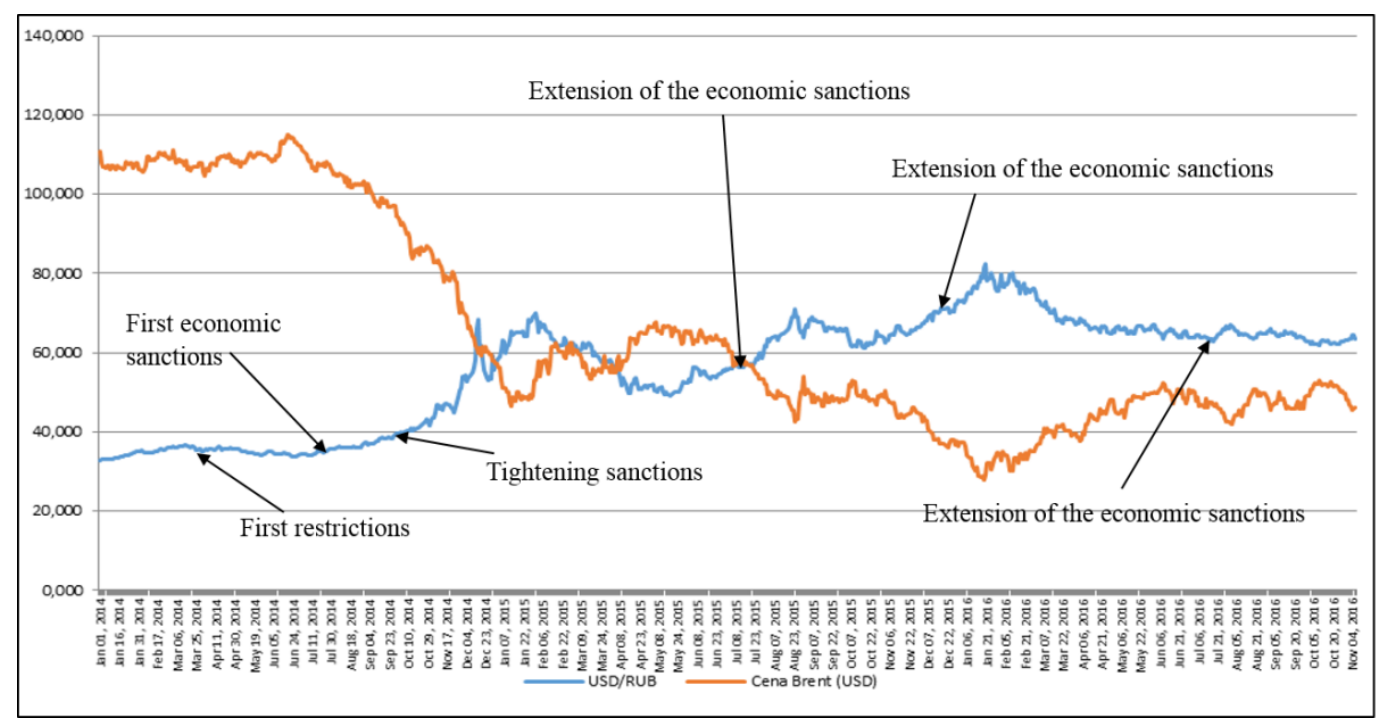

Figure 6. Oil price vs. ruble exchange rate

Source: Investing.com (2016a); Investing.com (2016b).

According to monetary policy of Russian Central Bank (2015) there should be unlikely any correlation between the oil prices and the ruble/USD exchange rate. In the document published by the Russian Central Bank (The Bank of Russia FX policy) there is stated that the ruble exchange rate is neither set by the Government nor fixed or targeting. Thus, there should be a regime of floating exchange rate. In other words the ruble exchange rate against foreign currencies should be set by the market, meaning the ratio between the demand for foreign currency and its supply in the FX market To understand better the eventual impact of sanctions and other factors on Russian economy and on exchange rate specifically it would be necessary to analyze the relation between ruble/USD exchange rate and BRENT oil prices using daily time series in the period from 02/01/2013 till 07/11/2016 (Figure 7). The time series is divided by the date of imposition of the first set of sanctions (29/07/2014). 


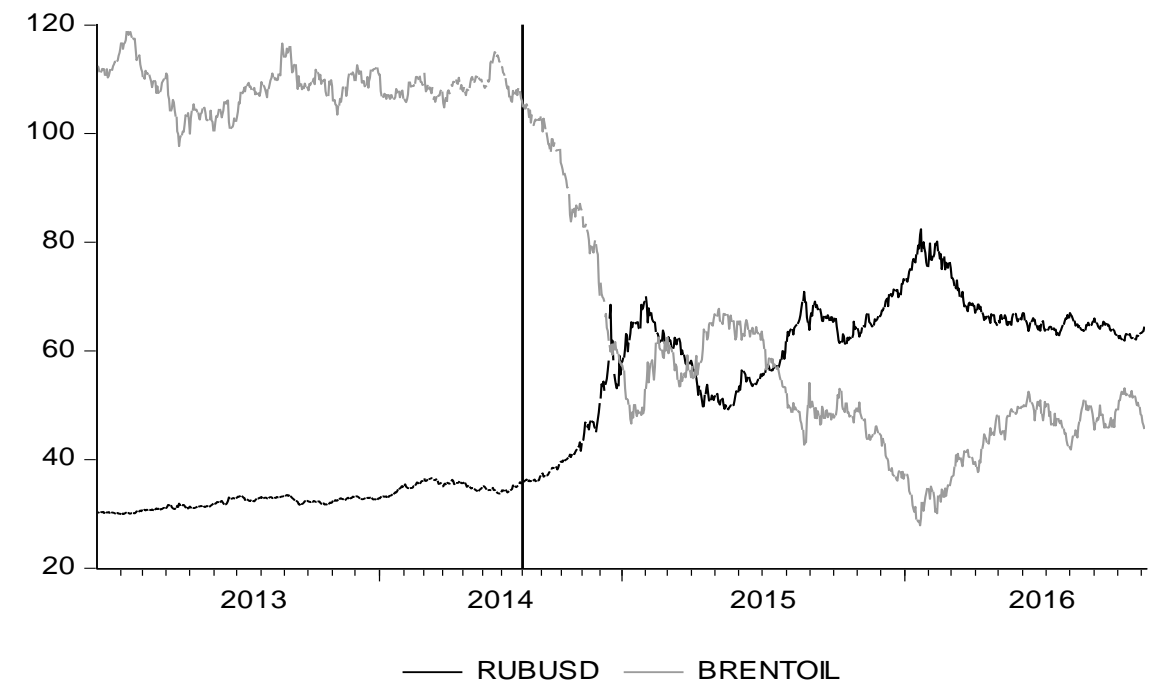

Figure 7. Ruble/USD exchange rate and the BRENT oil prices (in USD) in the period 02/01/2013-07/11/2016

Source: Investing.com (2016a); Investing.com (2016b).

According to tested hypotheses we divided the analysis into two parts. The first would analyze the mutual relation before the first imposition of sanctions, i.e. in the period from 02/01/2013 till 30/07/2014 and the second after the 30/07/2014 till the end of our time series.

In order to analyze the relations between the two time series, it is necessary first to test whether the two series integrated in the given periods are of the same order. The Table 1 shows the ADF unit root tests (Dickey and Fuller, 1979) of both time series divided into the aforementioned parts.

Table 1

Unit root test

\begin{tabular}{|c|c|c|c|c|c|c|}
\hline & \multicolumn{3}{|c|}{ Before sanctions } & \multicolumn{3}{c|}{ After sanctions } \\
& \multicolumn{2}{|c|}{$\mathbf{1 / 0 2 / 2 0 1 3}-\mathbf{7 / 3 0 / 2 0 1 4}$} & \multicolumn{3}{c|}{$\mathbf{7 1 / 2 0 1 4} \mathbf{~ 1 1 / 0 7 / 2 0 1 6}$} \\
\hline & t-Stat. & Prob. & type & t-Stat & Prob. & type \\
\hline RUBUSD & -2.8259 & 0.7750 & $\mathrm{I}(1)$ & -3.15226 & 0.5956 & $\mathrm{I}(1)$ \\
\hline BRENTOIL & -3.9007 & 0.1932 & $\mathrm{I}(1)$ & -3.90868 & 0.1902 & $\mathrm{I}(1)$ \\
\hline
\end{tabular}

Source: own calculations

The results indicate that both time series are non-stationary in both periods, i.e. integrated order 1 (I (1)). In such a case, that could lead to two situations between both time series. Time series could be either co-integrated with a long-term relation between them or the mutual relation could be identified only as apparent and thus without any long-term relation between both time series. To determine the nature of the relationship we use the Engle-Granger Cointegration test (Engle \& Granger, 1987). 
Engle-Granger test

\begin{tabular}{|l|c|l|l|l|l|l|l|l|}
\hline & \multicolumn{3}{|c|}{ Before sanctions } & \multicolumn{4}{c|}{ After sanctions } \\
& \multicolumn{3}{|c|}{$\mathbf{1 / 0 2 / 2 0 1 3}-\mathbf{7 / 3 0 / 2 0 1 4}$} & \multicolumn{3}{c|}{ 7/014 - 11/07/2016 } \\
\hline & tau-st. & Prob. & z-st. & Prob. & tau-st. & Prob. & z-st. & Prob. \\
\hline RUBUSD & -1.0413 & 0.8939 & -2.1993 & 0.9220 & -4.6283 & 0.0008 & -40.772 & 0.0005 \\
\hline BRENTOIL & -2.9941 & 0.1137 & -17.353 & 0.0922 & -4.6887 & 0.0006 & -40.436 & 0.0006 \\
\hline
\end{tabular}

Source: own calculations

Using the Engle-Granger Cointegration test (Table 2) tau-stat. data we may conclude that the residua of a simple regression model before sanctions (02/01/2013-30/07/2014) are nonstationary I(1), which confirms the eventual apparent regression; and model residua after imposition of sanctions $(31 / 07 / 2014$ 07/11/2016) are stationary $\mathrm{I}(0)$, which excludes the possibility of apparent regression."

The results make it obvious that there was no long-term relation between time series of RUBUSD and BRENTOIL before sanctions and in contrary we may expect that there could identified be a longterm relation after imposition of sanctions (31/07/2014-07/11/2016). From the above mentioned it is certain that further analysis will consider only the period after introduction of sanctions $(31 / 07 / 2014-$ 07/11/2016).

Z-stat values from Table 2 indicate, that after the introduction of sanctions the simple regression model residues include autocorrelation. This problem will be solved by dynamization of the model. The final ADL model is described in Table 3.

Table 3

ADL Model

\begin{tabular}{|c|c|c|c|c|}
\hline \multicolumn{5}{|c|}{ Dependent variable: RUBUSD } \\
\hline Variable & Coefficient & Std. Error & t-Statistic & Prob. \\
\hline $\mathrm{C}$ & 5.440655 & 1.532187 & 3.550909 & 0.0004 \\
\hline RUBUSD $(-1)$ & 0.941459 & 0.016595 & 56.73178 & 0.0000 \\
\hline BRENTOIL & 0.426240 & 0.038226 & -11.15047 & 0.0000 \\
\hline BRENTOIL(-1) & 0.392300 & 0.033750 & 11.62374 & 0.0000 \\
\hline R-squared & \multicolumn{2}{|l|}{0.992840} & D-W stat & 2.1237 \\
\hline F-statistic & \multirow{2}{*}{\multicolumn{2}{|c|}{31893.11}} & Prob(F-statistic) & 0.0000 \\
\hline Diagnostics tests & & & Statistics & Prob. \\
\hline \multicolumn{3}{|c|}{ Breusch-Godfrey Serial Correlation LM Test: } & 2.058499 & 0.1284 \\
\hline
\end{tabular}

Source: own calculations

Since we have daily data, which are usually influenced by heteroskedasticity, the estimates of parameters were obtained by using the corrected estimates of standard errors HAC (heteroscedasticity and autocorrelation consistent standard errors) (Newey \& West, 1987).

ADL model (Table 3) is thus in the following form:

$$
R \widehat{\operatorname{UBUS}} D_{t}=5.440655+0.941459 \text { RUBUSD }_{t-1}-0.42624 \text { BRENTOIL }_{t}+0.3923 \text { BRENTOIL }_{t-1}
$$

and it concludes that from the short-term relations perspective represented by ADL model, the RUBUSD value at time $t$ depends directly proportionally on its previous value and on the previous 
BRENTOIL value (i.e. in both cases on the value at time $t-1$ ); and there is an inversely proportional relation on BRENTOIL value in the same time $t$.

By redefining the model (1) to the form of error correction model

$$
\begin{aligned}
& \Delta R \widehat{U B U S D}_{t}=92.9375-0.42624 B R E N T O I L_{t}- \\
& -0.05854\left[\text { RUBUSD }_{t-1}+0.57976 \text { BRENTOIL }_{t-1}\right]
\end{aligned}
$$

we may split the short-term relations from the long-term ones. The system responds to deviations from the equilibrium by rate of 0.0585 and the value of the fixed multiplier is -0.57976 .

Table 4

Model EC

\begin{tabular}{|l|c|c|c|c|}
\hline \multicolumn{4}{|c|}{ Dependent Variable: RUBUSD } \\
\hline Method: Dynamic Least Squares (DOLS) \\
\hline \multicolumn{1}{|c|}{ Variable } & Coefficient & Std. Error & t-Statistic & Prob. \\
\hline \multicolumn{1}{|c|}{ BRENTOIL } & -0.57976 & 0.014562 & -39.81321 & 0.0000 \\
\hline R-squared & 0.933756 & Mean dependent var & 60.89601 \\
\hline Adjusted R-squared & 0.933564 & S.D. dependent var & 10.06843 \\
\hline Long-run variance & 41.80704 & & & \\
\hline
\end{tabular}

Source: own calculations

Long-term relation (Table 4) can then be expressed by the equation:

$$
R \widehat{R B U S} D_{t}=-0.57976 \text { BRENTOIL }_{t}
$$

Thus, we may conclude that the decrease of BRENTOIL by 1 USD would lead increase of RUBUSD rate in average by 0.58 , i.e. the ruble would weaken by 0.58 rubles to USD.

We tried to do the same analysis also for other periods, e.g. after imposing Russian countersanctions but there were no significant shifts in this rate.

\section{CONCLUSION}

As from the literature review as from the practice it is obvious that economic sanctions have negative effects on affected economies. Specifically, we may see that investors are divesting from sanctioned countries either because they revaluate their risks born in that country or because they are made to do so in order to obey sanction restrictions. The capital outflows have their evident impact on the economy and their qualitative indices. In case of Western sanctions imposed on Russia over the Ukraine crisis we also experienced the capital outflow from Russia. But the outflow was not caused exclusively because of the sanctions. It had actually started some months before introduction of sanctions because of a negative outlook on Russian economy because of its dependency on oil exports and declining oil prices.

From the perspective or Russian population the other measures taken by Western countries had rather an ambiguous impact, because they were targeting either few individuals or military and heavy industry. Looking at our analysis, we may say that it was more likely the countermeasures of Russian government, declining oil prices and managed exchange rate of ruble by Russian Central Bank that had much more evident impact on living standards of ordinary citizens. However, the Russian Central Bank claims that it is not managing the exchange rate of ruble, our analysis revealed that after the introduction of first sanctions against Russia there is an evident and pretty tight relation between the BRENT OIL prices and ruble exchange rate which could be hardly explained by other circumstances and which were 
not experienced before. The strength of the relationship between the oil price and the exchange rate of ruble has turned to be more or less stable after the June 30, 2014 up to now and the exchange rate reacts almost immediately on any oil price shifts.

Using our findings and the pursued analysis we can conclude that the present Russian economic condition depends on its dependence on oil exports and the current market prices on oil. Ordinary population is than more affected by Russian government countermeasures and especially by the development of the exchange rate of national currency. Taking into account the dependence of Russia on imports in many sectors, with the exception of raw materials, it is clear that ordinary Russians who perceive their economic reality mainly through the amount of their disposable income and purchasing power, are more than by Western sanctions influenced by the proven management of the exchange rate and its binding on oil prices.

\section{ACKNOWLEDGEMENTS}

This paper was supported by grant No. P402/12/G097 DYME "Dynamic Models in Economics" of the Czech Science Foundation.

\section{REFERENCES}

Bolotov, I. (2013). Analysis of the Retail Trade and Automotive Industry in the Russian Federation. Central European Business Review, 2(3), 7-14.

Caruso, R. (2003). The impact of international economic sanctions on trade: An empirical analysis. Peace Economics, Peace Science and Public Policy, 9(2).

Central Bank of the Russian Federation. (2016). External Sector Statistics: Net Inflows/Outflows of Capital by Private Sector (Based on the Balance of Payments, Flows Data). Retrieved 17/01/2017 from http://www.cbr.ru/eng/statistics/?Prtid=svs.

Council of the European Union. (2014). EU restrictive measures. Retrieved 01/01/2017 from http://www.consilium.europa.eu/uedocs/cms_data/docs/pressdata/EN/foraff/135804.pdf.

Dickey, D. A., \& Fuller, W. A. (1979). Distribution of the estimators for autoregressive time series with a unit root. Journal of the American statistical association, 74(366a), 427-431.

Dreyer, I., \& Popescu, N. (2014). Do sanctions against Russia work. European Union Institute for Security Studies, 35.

Engle, R. F., \& Granger, C. W. (1987). Co-integration and error correction: representation, estimation, and testing. Econometrica: journal of the Econometric Society, 55, 251-276.

European Union. (2014). EU sanctions against Russia over Ukraine crisis. Retrieved 02/01/2017 from https://europa.eu/newsroom/highlights/special-coverage/eu sanctions en.

Financial Services Monitor Worldwide. (2016). Russia's wealth fund will be down to $\$ 7.9$ bln in three years finance minister. Retrieved 05/01/2017 from http://search.proquest.com/docview/1824886145?accountid=17203.

Giumelli, F. (2011). Coercing, constraining and signalling: explaining UN and EU sanctions after the Cold War. ECPR Press.

Hille, K. (2014). Russian agriculture struggles to meet self-sufficiency challenge. Financial times. Retrieved 15/01/2017 from https:/ /www.ft.com/content/776c7c6a-2782-11e4-ae44-00144feabdc0.

Hufbauer, G., Schott J., Elliott K., \& Oegg, B. (2007). Economic Sanctions Reconsidered. 3d ed. Washington: Peterson Institute.

Investing.com. (2016a). Brent oil bistorical prices. Retrieved 05/01/2017 from http://www.investing.com/commodities/brent-oil.

Investing.com. (2016b). USD/RUB - US Dollar Russian Ruble. Retrieved 05/01/2017 from http://www.investing.com/currencies/usd-rub-historical-data.

О внесении изменений в постановление Правительства Российской Федерации от 7 августа 2014 г. № 778. Moscow. (2014). $\quad$ vol. $\quad 830, \quad$ Retrieved http://download.mpo.cz/get/51065/59418/619392/priloha003.pdf

(2014). Nařízení vlády RF ze dne 14. července 2014 č. 656 "O vydání zákazu přístupu určitých druhů strojírenských výrobků pocházejících z cizích států za účelem nákupů zajišt’ujících státní a obecní potřeby". Moscow, 656. 
Kaempfer, W. H., \& Lowenberg, A. D. (2007). The Political Economy of Economic Sanctions. Handbook of defense economics, 2, 867-911.

Lam, S. L. (1990). Economic sanctions and the success of foreign policy goals: a critical evaluation. Japan and the World Economy, 2(3), 239-248.

Ministry of Finance of the Russian Federation. (2016). Reserve Fund: Statistics - Volume of the Reserve fund. Retrieved 05/01/2017 from http://old.minfin.ru/en/reservefund/index.php.

Mirzayev, E. (2015). Sanctions \& Falling Oil Prices Hit Ruble Hard. Investopedia. Retrieved from http://www.investopedia.com/articles/investing/012115/sanctions-oil-prices-bring-russian-economy-nearcollapse.asp.

Newey, W. K., \& West, K. D. (1987). A Simple Positive Semi-Defi nite, Heteroskedasticity and Autocorrelation Consistent Covariance Matrix. Econometrica, 55, 703-708

Reuters. (2015). UPDATE 1-Russia's capital outflows reach record $\$ 151.5$ bln in 2014 as sanctions, oil slump hit. Retrieved from http://www.reuters.com/article/russia-capital-outflows-idUSL6N0UV3S320150116.

StatBureau. (2016). Russia Annual and Monthly Inflation Tables: Year over Year Inflation Table. Retrieved 31/12/2016 from https://www.statbureau.org/en/russia/inflation-tables.

Tarver, E. (2015). 4 Reasons Why the Price of Crude Oil Drop. Investopedia. Retrieved 18/01/2017 from http://www.investopedia.com/articles/investing/102215/4-reasons-why-price-crude-oil-dropped.asp.

Tran, P. (2015). Mistral Dispute With Russia Settled, France Eyes Exports. DefenseNews. Retrieved 18/01/2017 from http://www.defensenews.com/story/defense/naval/ships/2015/08/09/mistral-dispute-russia-settledfrance-eyes-exports $/ 31278439 /$. 